28/01/09

\title{
Adjusting soil infiltration coefficients for groundwater level
}

\section{James R. Blake MSci PhD}

Research Hydrologist

Centre for Ecology \& Hydrology, Wallingford, UK

Centre for Ecology \& Hydrology, Maclean Building, Crowmarsh Gifford, Wallingford, Oxfordshire, OX10 8BB, UK

Email: jarib@ceh.ac.uk

Phone: +44 (0)1491 692432

2842 Words, 1 Table, 3 Figures

Key words: Sewers \& drains, Groundwater, Drainage \& irrigation 


\section{ABSTRACT}

Current UK guidance for the design of sustainable drainage systems recommends that infiltration devices, such as soakaways, permeable pavements and infiltration basins, should be able to operate during periods of extreme groundwater level. Furthermore, higher groundwater levels have recently been shown to cause a reduction in the empirical soil infiltration coefficient, as used in the design of infiltration devices. However, there is currently no simple method available to estimate the required reduction in the design infiltration coefficient to account for an extreme groundwater level. This paper uses exploratory numerical sub-surface saturated-unsaturated hydrological modelling to quantify the effect of groundwater level on the infiltration coefficient for six typical soil types. The fixed resolution finite element simulations are also benchmarked against a solution employing adaptive mesh refinement. The modelling results are distilled into charts and a simple equation to allow the calculation of adjustment factors, with which to reduce the design infiltration coefficient to account for a higher design groundwater level. Varying soil type sensitivity is highlighted. These factors could also be used to correct for soakage tests made during periods of lower groundwater level. Threshold depths to groundwater, below which no adjustment is required, are identified for each soil type.

\section{NOTATION}

$\begin{array}{ll}a_{p 50} & \text { wetted internal surface area (sides and base) of soakage test pit at } 50 \% \text { of } \\ h & \text { effective depth }\left(\mathrm{m}^{2}\right) \\ k & \text { pore water pressure head }(\mathrm{m}) \\ K & \text { infiltration coefficient adjustment factor }(-) \\ & \text { hydraulic conductivity }(\mathrm{m} / \mathrm{s})\end{array}$




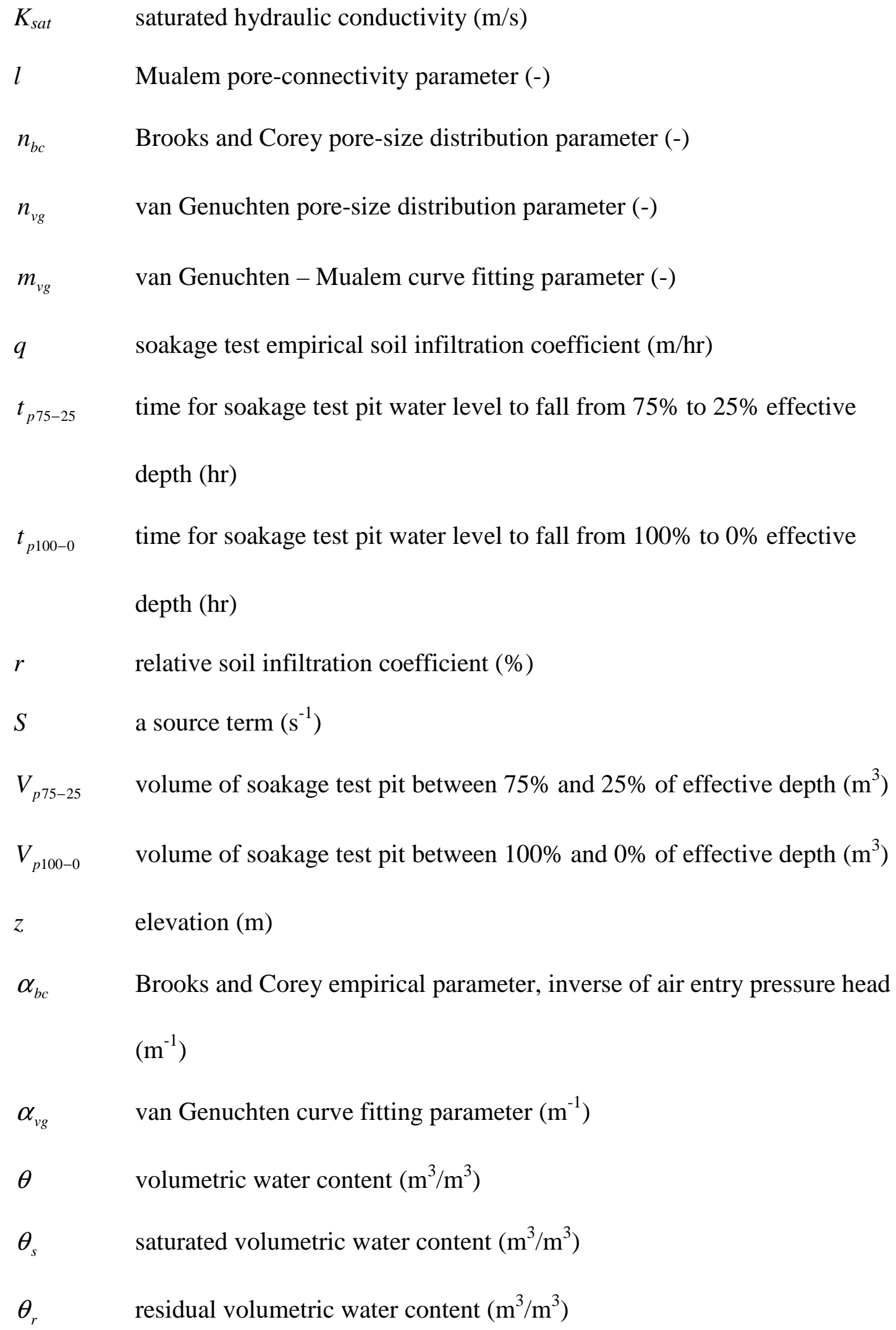




\section{INTRODUCTION}

Current UK guidance ${ }^{1}$ for the design of sustainable drainage systems (SuDS) recommends that infiltration devices, such as soakaways, permeable pavements and infiltration basins, should be able to operate during periods of extreme groundwater level (defined as 'up to 1 per cent annual probability'). A key variable used to design such devices ${ }^{1-3}$ is the empirical soil infiltration coefficient, $q$, as determined using a field soakage test procedure (see Appendix). Recent modelling has identified that, above a threshold depth, groundwater level exerts a significant control on the infiltration coefficient and, providing the soakage test is conducted in accordance with best practice guidance ${ }^{1-3}$ (i.e. using three successive drain downs, allowing the infiltration coefficient to approach a minimum value), seasonal antecedent soil moisture is much less important. ${ }^{4}$ It was also inferred that seasonal variation in the infiltration coefficient measured using a series of soakage tests at the same site in Nottingham, UK (indicating a winter minimum and a summer maximum), ${ }^{5}$ was most likely caused by changing groundwater levels. ${ }^{4}$ This is supported by field observations of infiltration rates in Nevada, USA, which were found to have a significant positive correlation with depth to groundwater. ${ }^{6}$ Furthermore, analysis of monitored soakaway and groundwater levels given for a site in Aberdeen, UK, ${ }^{7}$ indicates that the average infiltration rate during initial soakaway half-emptying can decrease significantly for higher groundwater levels. Localised groundwater rise (mounding) has also been recognised as a major cause of infiltration basin failure ${ }^{8-10}$ and prolonged emptying times ${ }^{11}$.

Given the control that groundwater level exerts on the soil infiltration coefficient, and the recommendation in current SuDS design guidance to account for an extreme 
groundwater level, it is surprising that, to the best of the author's knowledge, there is no simple method available to quantify such effects. Therefore, the aim of this paper is to provide simple adjustment factors for typical soils, which give a first indication of the necessary reduction in the design infiltration coefficient to account for a higher design groundwater level. As field test derived results would be constrained by natural groundwater variability, this initial study will employ exploratory numerical modelling. The procedures outlined by Blake ${ }^{4}$ will be followed to simulate soakage tests in a range of soil types indicated as suitable for infiltration drainage. ${ }^{1}$ The model domain will be expanded to include greater depths to groundwater to allow thresholds to be identified for each soil type. The modelling results will be distilled into design charts and a simple equation. The adjustment factors can also be used to compensate for soakage testing carried out during periods of lower groundwater levels (e.g. droughts or summer).

\section{THEORY AND MODEL SELECTION}

As before, ${ }^{4}$ the soakage testing will be modelled using the FEFLOW ${ }^{\circledR} 5.2$

(DHI-WASY GmbH, Berlin, Germany ${ }^{12-14}$ ) physically based distributed finite element (FE) code, solving the 'mixed' version of the Richards equation for saturatedunsaturated incompressible fluid flows in an incompressible media:

$$
\left.\frac{\partial \theta}{\partial t}=\underline{\nabla} \underline{\underline{K}} \underline{\nabla}(h+z)\right)+S
$$

where $\theta$ is volumetric water content $\left(\mathrm{m}^{3} / \mathrm{m}^{3}\right), t$ is time (s), $\underline{\underline{K}}$ is the hydraulic conductivity tensor $(\mathrm{m} / \mathrm{s}), h$ is pore water pressure head $(\mathrm{m}), z$ is elevation $(\mathrm{m})$ and $S$ is a source term $\left(\mathrm{s}^{-1}\right)$. 
To balance computational speed, numerical convergence and mass conservation, the following FEFLOW options ${ }^{14,15}$ were selected. Transient simulations: Galerkinbased 3-node triangular FE method, lumped mass matrices, analytic derivative for the capacity term, central weighting for the influence coefficient, Newton iteration scheme, preconditioned Lanczos BiCGSTABP iterative solver, adaptive time stepping strategy using a forward Euler / backward Euler time integration, a maximum of 12 iterations per time step and 1E-3 maximum error norm. Hydrodynamic steady state simulations: identical, except for: h-based Richards equation, Picard iteration scheme, preconditioned conjugate gradient iterative solver and 1E-6 maximum error norm. Hysteresis, air entrapment and macropore flow have been excluded and the subsurface materials are assumed isotropic and homogeneous.

\section{MODEL GEOMETRY, DISCRETISATION AND PARAMETERISATION}

Fig. 1 shows the model geometry and discretisation. The section is rotated about the z-axis, giving a three dimensional axisymmetric problem that can be modelled in two dimensions. Compared to the previous modelling, ${ }^{4}$ the test pit extent now reflects soakage test practice more accurately. The invert level of the proposed input pipe(s) is $0.75 \mathrm{~m}$ below the surface (I, in Fig. 1). This accounts for the Building Regulations ${ }^{16}$ minimum cover thickness for pipes laid in fields $(0.6 \mathrm{~m})$ and an assumed $150 \mathrm{~mm}$ pipe diameter. The test pit base remains at $2.00 \mathrm{~m}$ below the surface, a typical soakaway depth. ${ }^{2}$ Then, given a typical water bowser capacity of 500 gallons $\left(2.273 \mathrm{~m}^{3}\right)$, the pit radius is specified as $0.75 \mathrm{~m}$. This gives an effective test pit volume (i.e. below the invert level) of $2.209 \mathrm{~m}^{3}$, which meets the $2 \mathrm{~m}^{3}$ minimum for drained areas over $100 \mathrm{~m}^{2}$ from CIRIA C697. ${ }^{1}$ The lower domain boundary has been extended further away from the test pit to allow groundwater levels up to $8 \mathrm{~m}$ below 
the pit base to be simulated. To avoid boundary effects propagating back to the area of interest, the right hand boundary was again located a reasonable distance from the test pit. The FE mesh contains about 40,000 elements, with increased resolution near the test pit and the surface. The element side length varies from 6 to $12 \mathrm{~cm}$.

Current guidance ${ }^{1}$ highlights eight soil textural types which are good infiltration media. Of these, Gravel and Chalk have been excluded from the current modelling because: (i.) flows in chalk require a dual-permeability model, e.g. Mathias et al. ${ }^{17}$; and (ii.) Richards equation is unlikely to be valid for infiltration into gravels due to both turbulent flow ${ }^{18}$ (caused by large pore sizes and a high hydraulic gradient) and unstable flow phenomena. ${ }^{19}$ The six remaining soil types (Loam, Loamy Sand, Silt Loam, Sand, Sandy Clay Loam and Sandy Loam) have been selected for modelling. For each of these soil types, Carsel and Parrish ${ }^{20}$ have documented mean hydrological parameter values as used in the van Genuchten ${ }^{21}-$ Mualem $^{22}$ (VG-M) representation of the soil constitutive functions $\theta(h)$ and $K(h)$. This data will be used as a basis to parameterise the soil types in the current study. Recent research has however identified shortcomings in the original van Genuchten $\theta(h)$ function, ${ }^{23}$ specifically when the pore-size distribution parameter, $n_{v g}$, is less than $2.0^{24}$ (as is the case for many of the soil types summarised by Carsel and Parrish). To avoid this problem, the current study uses the Brooks and Corey ${ }^{25}$ - Mualem ${ }^{22}$ (BC-M) formulation of the constitutive functions and the $n_{v g}$ values have been converted to their BC-M equivalents ( $n_{b c}$ ) using known relationships. ${ }^{26}$ It is assumed that the poreconnectivity parameter, $l$, equals 0.5 (Mualem's average value). Table 1 lists the parameters used. In addition, for each modelled soil type an equivalent ISO 14688-1:2002 soil classification ${ }^{27}$ is given, so that the study findings can be more 
easily related to site investigation reports. These have been defined according to the centroid of the sub-region covered by each soil type on the US Department of Agriculture soil texture classification triangle ${ }^{28}$ (as used to classify the soil types summarised by Carsel and Parrish).

As previously, ${ }^{4}$ when initial conditions are being generated the test pit volume is specified as soil, then during the soakage test simulations it is re-specified as 'air' 29 (or a 'highly permeable auxiliary material' ${ }^{30}$ ). The 'air' is parameterised using the VG-M constitutive functions, along with the suggestion ${ }^{21}$ that the curve fitting parameter, $m_{v g}$, should equal $1-n_{v g}^{-1}$ (see Table 1 for values). Accounting for water initially held above the test pit fill level, the water retained under tension in the unsaturated 'air' when the test pit is empty is less than $5 \%$ of the water added to the pit.

\section{SOAKAGE TEST MODELLING}

For each soil type, nine groundwater levels were modelled $(0.5,1.0,1.5,2.0,3.0,4.0$, 5.0, 6.0 and 8.0 m below the test pit base; $C_{1}$ to $C_{9}$ in Fig. 1), giving a matrix of 54 soakage test scenarios to simulate. Seasonal antecedent unsaturated zone soil moisture has little effect on the measured infiltration coefficient, providing that best practice of using three successive drain downs for the soakage test is followed ${ }^{4}$ (see Appendix). However, simulating infiltration into an initially wetter soil will be less computationally demanding. Therefore, a hydrodynamic steady state ${ }^{31}$ procedure $^{4,32,}$ ${ }^{33}$ has been used to generate initial conditions representing winter soil moisture for each soil type and groundwater level scenario. As before, a flux equivalent to the average effective 'winter' rainfall for southern England ${ }^{34}(1.89 \mathrm{E}-3 \mathrm{~m} / \mathrm{d}$, assuming 
$0.5 \mathrm{~mm} /$ day evaporation) has been applied into the domain along the surface boundary (AB in Fig. 1). A specified hydrostatic head condition has been applied to the right boundary below the groundwater level (i.e. CD). All other boundaries are zero flux. Using an arbitrary starting point (hydrostatic with respect to the boundary groundwater level), a transient simulation is then run for 5000 days using adaptive time-stepping. This is sufficient time for the hydrodynamic steady state conditions to be generated (as indicated when the net boundary flux reaches zero).

For each scenario, having generated the hydrodynamic steady state initial conditions, the soakage test procedure (see Appendix) is then simulated using transient simulations: All boundaries are set to zero flux, apart from the right boundary (CD in Fig. 1) which, with respect to the initial groundwater level, has a specified hydrostatic head condition. The test pit excavation is simulated by re-specifying the relevant soil volume as 'air' (see Fig. 1). The hydraulic head for the 'air' elements is then changed to $11.25 \mathrm{~m}$ to represent the pit being instantaneously filled with water to the proposed pipe invert level. A transient simulation is then run so that the pit can drain to empty (simulation length: 1 day for Loamy Sand and Sand, 3 days for Sandy Loam and 7 days for Loam, Silt Loam and Sandy Clay Loam). Recorded output times were specified at 0 minutes and, as appropriate, at six equal increments between each of 1060 minutes, 80-180 minutes, 210-360 minutes, 7-12 hours, 14-24 hours, 28-48 hours, 56-96 hours and 4.5-7 days inclusive. The hydraulic head at point P (Fig. 1) was recorded at each numerical time step as this represents the water surface elevation in the test pit (since the water in the pit remains hydrostatic). Having completed the first drain down, the test pit water surface decline over time was examined to identify the first recorded output time after the pit had emptied. The pressure head distribution at 
this output time is then used as the initial conditions for the next refill and drain down cycle. This is repeated once more, giving three successive drain downs. The simulations took a total of 315 hours on an Intel Core 2 Duo $3 \mathrm{GHz}$ PC. The mean mass balance error was $0.02 \%$, the maximum was $0.1 \%$.

Recent research by Vogel and Ippisch ${ }^{35}$ has identified an upper spatial discretisation limit for an unbiased solution of Richards equation. Using their method, the critical discretisation scales for the current soils are estimated to be: $0.4 \mathrm{~cm}$ (Sand), $0.6 \mathrm{~cm}$ (Loamy Sand), $1.2 \mathrm{~cm}$ (Sandy Loam), $3 \mathrm{~cm}$ (Loam and Sandy Clay Loam) and $6 \mathrm{~cm}$ (Silt Loam). These are for the worst case condition of the lowest antecedent groundwater level (which generates the largest hydraulic gradient between the water in the test pit and the underlying soil). Apart from the Silt Loam, the critical discretisation scales are significantly smaller than the fixed resolution element side length $(6 \mathrm{~cm})$ in the test pit region, indicating that the current solution might be inaccurate. To investigate this, a typical fixed resolution simulation (first drain down for the Loamy Sand with an antecedent groundwater level $3.0 \mathrm{~m}$ below the pit base) was benchmarked against an adaptive mesh refinement (AMR) FEFLOW simulation ${ }^{14}$ (with identical settings, except for h-based Richards equation, Picard iteration scheme, preconditioned conjugate gradient iterative solver and 1E-2 adaptive mesh error using Onate-Bugeda a posteriori error estimator). The AMR simulation used up to 250,000 elements. The infiltration coefficient was calculated for each simulation using the data recorded at point $\mathrm{P}$ and Equation 3 (Appendix). The infiltration coefficient for the fixed mesh resolution simulation was less than $0.07 \%$ larger than that for the AMR simulation, indicating that the current 40,000 element fixed resolution mesh is unlikely to be significantly less accurate than AMR for the scenarios modelled. 
Computational limitations mean that AMR is currently impractical for simulating large scenario matrices (the trial simulation took four times longer, and generated an output file an order of magnitude larger, than the fixed resolution simulation).

\section{RESULTS}

Since plots of the soil pore water pressure head development over time in response to the infiltrating water from the draining soakage test pit, and plots of the test pit water level decline over time, are similar to those published previously, ${ }^{4}$ they are not replicated here. For each idealised soil and groundwater level scenario, the minimum infiltration coefficient (from the three drain downs) has been calculated using the recorded pit water level decrease over time and the methodology given in the Appendix. 'Full depth' infiltration coefficients have also been calculated using the alternative methodology also given in the Appendix. The results for the Loamy Sand are slightly different to the previous modelling ${ }^{4}$ as the soakage test pit volume has been reduced in the current application. For each soil type, the infiltration coefficient for each groundwater level has been expressed as a percentage of the maximum infiltration coefficient for that soil type (i.e. that occurring when the groundwater level is below the threshold depth, e.g. at $8.00 \mathrm{~m}$ below the pit base). Figures 2 and 3 show changes in these relative infiltration coefficients, $r$, with groundwater level for each soil type, including an indication of the threshold depth, below which the infiltration coefficient is insensitive to groundwater level. There is slight variation in the relative infiltration coefficient about the $100 \%$ value (at different depths). This is due to the varying time elapsed between when the pit empties and the next available output time (which is subsequently used as initial conditions for the next drain down). 


\section{DISCUSSION}

Figures 2 and 3 can be used to calculate an adjustment factor, $k$, to reduce the infiltration coefficient, if necessary, to account for a higher design groundwater level:

$$
k=\frac{r_{\text {design }}}{r_{\text {original }}}
$$

where $r_{\text {original }}$ is the relative infiltration coefficient for the original groundwater level (at the time of the soakage test) and $r_{\text {design }}$ is the relative infiltration coefficient for the design groundwater level. For example, for a Sand soil and the original infiltration coefficient equation (Fig. 2), if the original groundwater level was $2.00 \mathrm{~m}$ below the pit base $\left(r_{\text {original }}=97.5 \%\right)$ and the design groundwater level is $1.00 \mathrm{~m}$ $\left(r_{\text {design }}=77.5 \%\right)$, the adjustment factor is 0.79 (which is then multiplied against the calculated infiltration coefficient). Importantly, if the design extreme groundwater level remains below the threshold depth, no adjustment is required (i.e. $k=1$ ). The adjustment factor should be applied in addition to any factor of safety used to reduce the infiltration coefficient to account for a performance reduction over time ${ }^{1}$ (e.g. due to clogging). Figures 2 and 3 highlight the importance of reducing the field-measured infiltration coefficient to account for a higher design groundwater level, particularly if the extreme groundwater level is expected to rise to within two meters or less of the infiltration device base, or if the soil type is silt rather than sand. In general, as groundwater rises to within a metre of an infiltration device (the minimum depth to groundwater suggested in current guidance ${ }^{1}$ ), the infiltration coefficient will have decreased to about two thirds of its maximum value. Soakage test data cited by Pratt, ${ }^{5}$ indicated that the infiltration coefficient at a particular location varied by a factor of three between a winter minimum and a summer maximum. Although the concomitant 
antecedent groundwater level was not measured, this study indicates that the winter groundwater level was likely to have been within $0.5 \mathrm{~m}$ of the test pit base.

\section{CONCLUSIONS}

Numerical modelling has been used to provide adjustment factors for a range of typical soils, which give a first indication of the necessary reduction in the design infiltration coefficient to account for a higher design groundwater level. Of practical importance is that soil-specific threshold depths have been identified, meaning that the design infiltration coefficient will not need to be adjusted unless the extreme groundwater level exceeds the relevant threshold. Future work should consider: (i.) conducting a series of soakage tests at a location known to experience large variations in groundwater level, in order to compare the new infiltration coefficient adjustment factors and thresholds against field measurements, potentially validating the methodology for use in practice; (ii.) extending the modelling analysis to gravel and chalk infiltration media; and (iii.) assessing the effect of soil heterogeneity and anisotropy.

\section{ACKNOWLEDGEMENTS}

The work presented in this paper has been developed under Water Cycle Management for New Developments (WaND) and the project support from EPSRC and industrial collaborators acknowledged. NERC provided additional support. I would also like to thank the two anonymous reviewers for their constructive comments.

\section{APPENDIX}

Soakage Test Procedure (after BRE Digest $365^{2}$ and CIRIA Report C697 ${ }^{1}$ ) 
(i.) Excavate a test pit, with vertical sides, to the same depth as the proposed infiltration device. The minimum pit volume should be $0.5 \mathrm{~m}^{3}$ for drained areas up to $100 \mathrm{~m}^{2}, 2 \mathrm{~m}^{3}$ for areas over $100 \mathrm{~m}^{2}$.

(ii.) Rapidly fill the pit with water to the maximum effective depth (i.e. the invert level of the proposed input pipe(s)).

(iii.) Allow the pit to drain, recording the water level fall over time.

(iv.) Repeat the filling/emptying cycle twice more, ideally on the same day.

(v.) For each set of drain down data, calculate the soil infiltration coefficient using:

$$
q=\frac{V_{p 75-25}}{a_{p 50} \times t_{p 75-25}}
$$

where $V_{p 75-25}$ is the volume of the pit between $75 \%$ and $25 \%$ of the effective depth, $a_{p 50}$ is the wetted internal surface area (sides and base) of the pit at $50 \%$ of the effective depth and $t_{p 75-25}$ is the time for the water level to fall from $75 \%$ to $25 \%$ of the effective pit depth.

(vi.) The smallest value of $q$ from the three repetitions should be used for design.

An alternative 'full depth' infiltration coefficient equation has also been suggested ${ }^{4}$ :

$$
q=\frac{V_{p 100-0}}{a_{p 50} \times t_{p 100-0}}
$$

where $V_{p 100-0}$ is the volume of the pit between $100 \%$ and $0 \%$ of the effective depth and $t_{p 100-0}$ is the time for the water level to fall from $100 \%$ to $0 \%$ of the effective depth. Unlike Equation 3, this equation is not biased towards the initial, more rapid, infiltration rate, although its use may present practical difficulties. ${ }^{4}$ 


\section{REFERENCES}

1. Woods-Ballard B., Kellagher R., Martin P., JefFeries C., BRAy R. and SHAFFER P. The SUDS Manual. Construction Industry Research and Information Association, London, 2007, C697.

2. Building Research Establishment. Soakaway design. BRE, Watford, 1991, Digest 365.

3. BETTESS R. Infiltration drainage - Manual of good practice. Construction Industry Research and Information Association, London, 1996, R156.

4. BLAKE J. R. Soakage testing - modelling the effect of antecedent hydrology. Proceedings of the Institution of Civil Engineers-Water Management, in press.

5. PRATT C. J. Research and development in methods of soakaway design. Journal of the Chartered Institution of Water and Environmental Management, 1996, 10, No. 1, 47-51.

6. Fennemore G. G., Davis A., Goss L. and Warrick A. W. A rapid screeninglevel method to optimize location of infiltration ponds. Ground Water, 2001, 39, No. 2, 230-238.

7. SIDDIQUi R. and POKRAJAC D. Parameters affecting emptying rate of infiltration drainage systems. SUDSnet, Dundee, 2004. See http://www.sudsnet.abertay.ac.uk/documents/RubinaSiddiqui_ParametersAffe ctingEmptyingRateofInfiltrationDrainageSystems.pdf for further details. Accessed 26/03/09.

8. Lawrence A. I., MarsaleK J., Ellis J. B. and Urbonas B. Stormwater detention \& BMPs. Journal of Hydraulic Research, 1996, 34, No. 6, 799-813. 
9. ELLIS J. B. Infiltration systems: A sustainable source-control option for urban stormwater quality management? Journal of the Chartered Institution of Water and Environmental Management, 2000, 14, No. 1, 27-34.

10. ElLIS J. B. Groundwater pollution from infiltration of urban stormwater runoff. In Groundwater in the Urban Environment: Volume 1: Problems, Processes and Management. (CHILTON J. (ed.)). Balkema, Rotterdam, 1997, pp. 131-136.

11. GuO J. C. Y. Design of circular infiltration basin under mounding effects. Journal of Water Resources Planning and Management-Asce, 2001, 127, No. $1,58-65$.

12. See http://www.feflow.info/

13. DIERSCH H.-J. G. FEFLOW $W^{\circledR}$ Reference Manual. WASY, Berlin, 2002.

14. DiERSCH H.-J. G., SCHÄtZl P., GRÜNDLER R. and ClaUSNitZER V. FEFLOW ${ }^{\circledR}$ 5.2 User's Manual. WASY, Berlin, 2005.

15. DIERSCH H.-J. G. FEFLOW ${ }^{\circledR}$ White Papers Vol. I. WASY, Berlin, 2004.

16. OfFICE OF THE DEPUTY PRIME MinISTER. The Building Regulations 2000, Approved Document H, Drainage and waste disposal. NBS, Newcastle upon Tyne, 2002.

17. Mathias S. A., Butler A. P., Jackson B. M. and Wheater H. S. Transient simulations of flow and transport in the Chalk unsaturated zone. Journal of Hydrology, 2006, 330, No. 1-2, 10-28.

18. BORDIER C. and ZIMMER D. Drainage equations and non-Darcian modelling in coarse porous media or geosynthetic materials. Journal of Hydrology, 2000, 228, No. 3-4, 174-187. 
19. OR D. Scaling of capillary, gravity and viscous forces affecting flow morphology in unsaturated porous media. Advances in Water Resources, 2008, 31, No. 9, 1129-1136.

20. CARSEl R. F. and PARRISH R. S. Developing Joint Probability Distributions of Soil Water Retention Characteristics. Water Resources Research, 1988, 24, No. 5, 755-769.

21. VAN GENUCHTEN M. T. A closed-form equation for predicting the hydraulic conductivity of unsaturated soils. Soil Science Society of America Journal, 1980, 44, 892-898.

22. MUALEM Y. A new model for predicting the hydraulic conductivity of unsaturated porous media. Water Resources Research, 1976, 12, No. 3, 513522.

23. SchaAp M. G. and VAn GenUChten M. T. A modified Mualem-van Genuchten formulation for improved description of the hydraulic conductivity near saturation. Vadose Zone Journal, 2006, 5, No. 1, 27-34.

24. IPPisch O., Vogel H. J. and Bastian P. Validity limits for the van GenuchtenMualem model and implications for parameter estimation and numerical simulation. Advances in Water Resources, 2006, 29, No. 12, 1780-1789.

25. BROOKS R. H. and COREY A. T. Hydraulic properties of porous media. Colorado State University, Fort Collins, Colorado, USA, 1964, Hydrology Paper No. 3.

26. Van Genuchten M. T., LeiJ F. J. and Yates S. R. The RETC Code for Quantifying the Hydraulic Functions of Unsaturated Soils. U. S. Environmental Protection Agency, Oklahoma, 1991, EPA/600/2-91/065. 
27. BRITISH STANDARDS INSTITUTION. Geotechnical investigation and testing Identification and classification of soil - Part 1: Identification and description. BSI, London, 2002, BS EN ISO 14688-1:2002.

28. Goudie A., Atkinson B. W., Gregory K. J., Simmons I. G., Stoddart D. R. and Sugden D. (eds.) The Encyclopedic Dictionary of Physical Geography, 2nd edn. Blackwell, Oxford, 1994.

29. DIERSCH H.-J. G. Treatment of free surfaces in $2 \mathrm{D}$ and $3 \mathrm{D}$ groundwater modeling. In FEFLOW White Papers Vol. I. (DIERSCH H.-J. G. (ed.)). WASY, Berlin, 2004, pp. 67-100.

30. Göbel P., Stubbe H., Weinert M., Zimmermann J., FACH S., Dierkes C., Kories H., Messer J., Mertsch V., Geiger W. F. and Coldewey W. G. Near-natural stormwater management and its effects on the water budget and groundwater surface in urban areas taking account of the hydrogeological conditions. Journal of Hydrology, 2004, 299, No. 3-4, 267-283.

31. Anderson M. P. and Woessner W. W. Applied Groundwater Modeling Simulation of flow and advective transport. Academic Press, San Diego, 1992.

32. BLAKE J. R. Modelling the dynamic interaction between hillslope hydrology and retaining structures (Hydrology and retaining wall stability model: HYDRET). PhD thesis, University of Bristol, Bristol, 2003.

33. Blake J. R., Renaud J.-P., Anderson M. G. and Hencher S. R. Prediction of rainfall-induced transient water pressure head behind a retaining wall using a high-resolution finite element model. Computers and Geotechnics, 2003, 30, No. 6, 431-442. 
34. See

http://www.metoffice.gov.uk/climate/uk/averages/19712000/areal/england_s.h $\underline{\mathrm{tml}}$

35. Vogel H. J. and IPPISCH O. Estimation of a critical spatial discretization limit for solving Richards' equation at large scales. Vadose Zone Journal, 2008, 7, No. 1, 112-114. 


\section{CAPTIONS}

Fig. 1. Radial section of modelled domain showing geometry, finite element mesh and material distribution. The section is rotated about the z-axis. Gravity is in the negative z-direction.

Fig. 2. Chart for calculation of infiltration coefficient adjustment factor to account for design groundwater level for different soil types (applicable to original infiltration coefficient equation, see Equation 3; ISO 14688-1:2002 soil classifications given in parentheses)

Fig. 3. Chart for calculation of infiltration coefficient adjustment factor to account for design groundwater level for different soil types (applicable to 'full depth' infiltration coefficient equation, see Equation 4; ISO 14688-1:2002 soil classifications given in parentheses)

Table 1. Hydrological parameters (ISO 14688-1:2002 soil classifications given in parentheses) 
Blake: Fig. 1

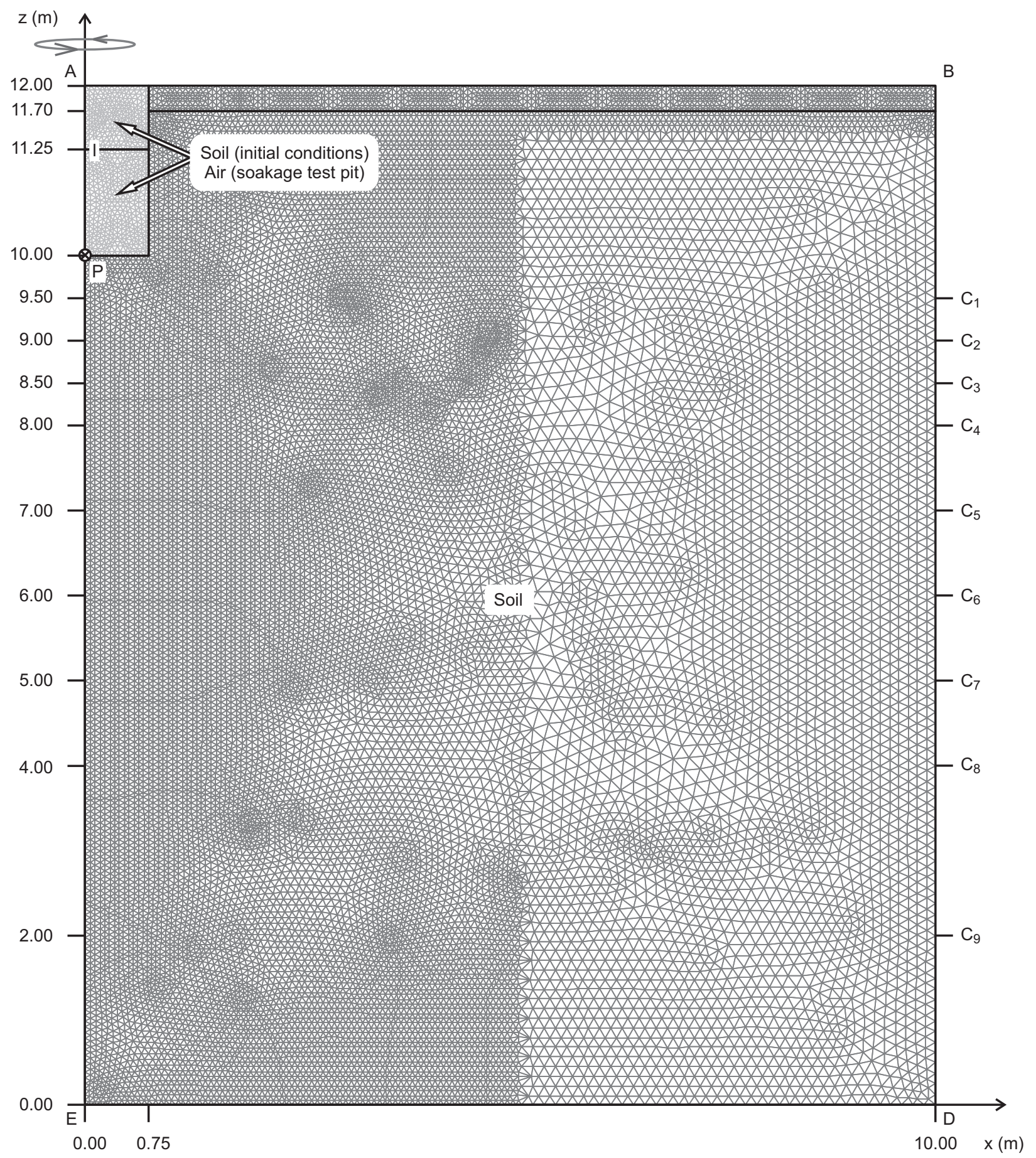


Blake: Fig. 2

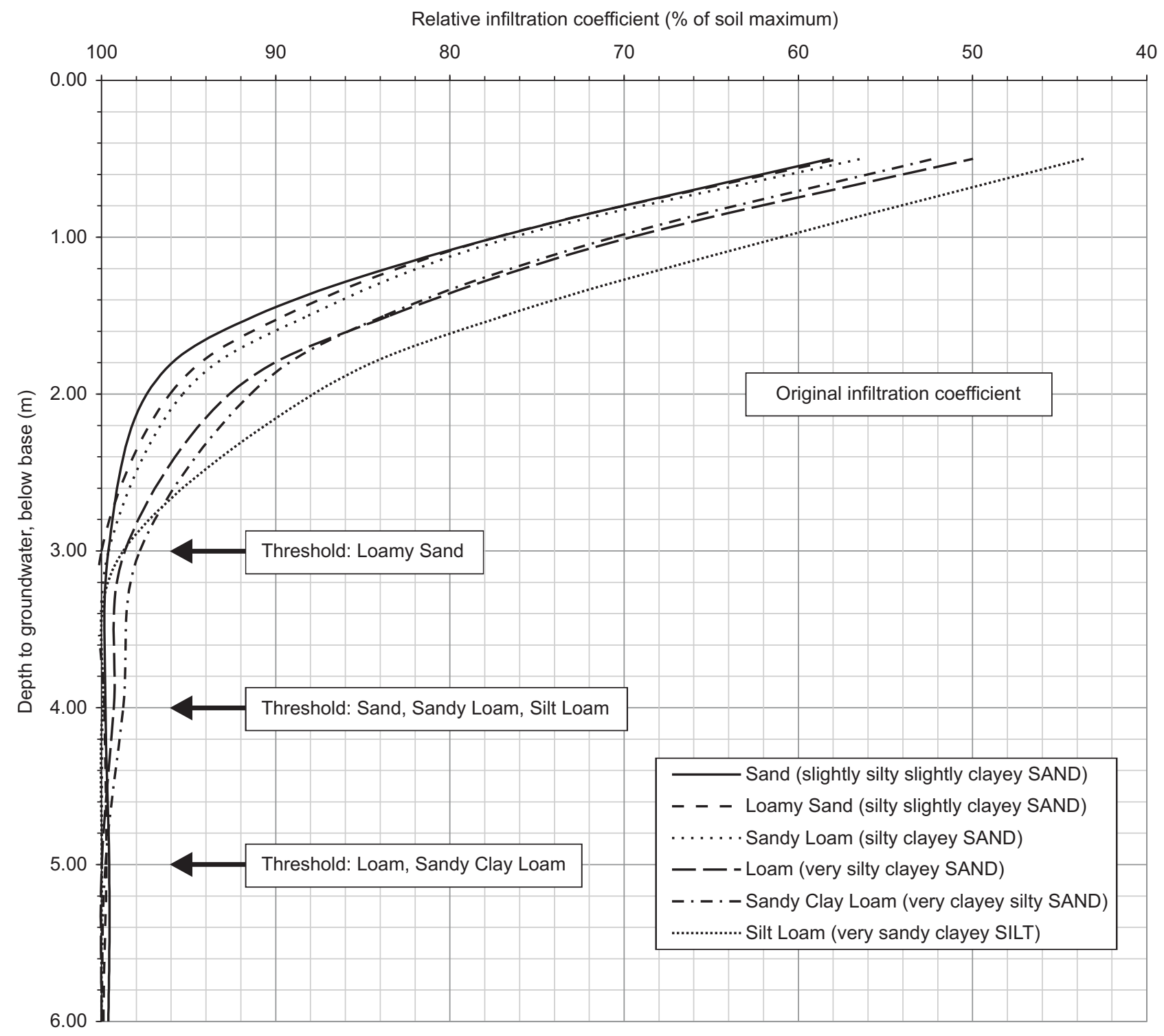




\section{Blake: Fig. 3}

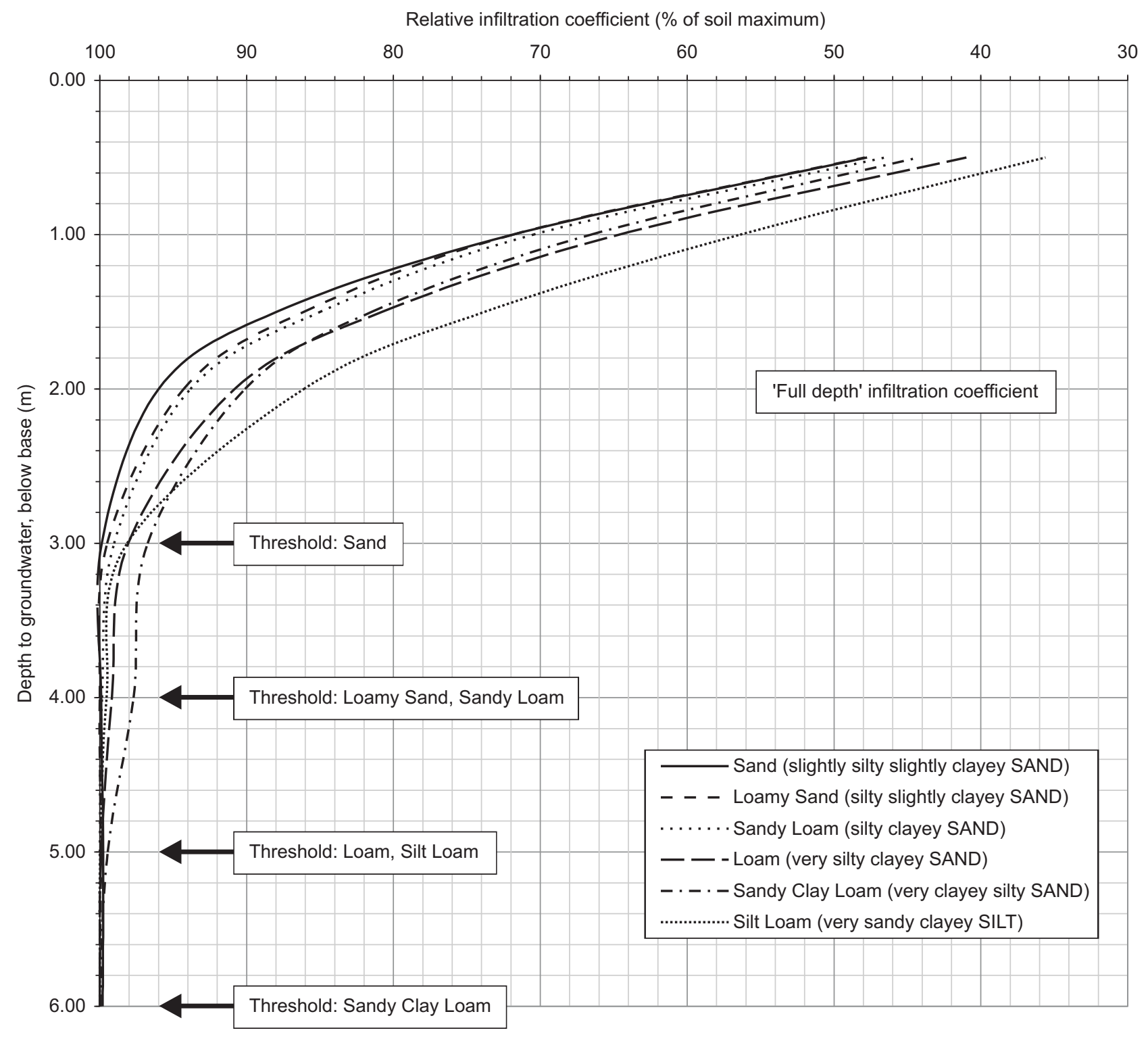




\section{TABLES}

Table 1.

\begin{tabular}{|c|c|c|c|c|c|c|c|}
\hline \multirow{3}{*}{ Parameter } & \multicolumn{7}{|c|}{ Material } \\
\hline & Loam & $\begin{array}{c}\text { Loamy } \\
\text { Sand }\end{array}$ & Silt Loam & Sand & $\begin{array}{l}\text { Sandy } \\
\text { Clay } \\
\text { Loam }\end{array}$ & $\begin{array}{l}\text { Sandy } \\
\text { Loam }\end{array}$ & \multirow[b]{2}{*}{ 'Air' } \\
\hline & $\begin{array}{l}\text { (very silty } \\
\text { clayey } \\
\text { SAND) }\end{array}$ & $\begin{array}{c}\text { (silty } \\
\text { slightly } \\
\text { clayey } \\
\text { SAND) }\end{array}$ & $\begin{array}{l}\text { (very } \\
\text { sandy } \\
\text { clayey } \\
\text { SILT) }\end{array}$ & $\begin{array}{l}\text { (slightly } \\
\text { silty } \\
\text { slightly } \\
\text { clayey } \\
\text { SAND) } \\
\end{array}$ & $\begin{array}{c}\text { (very } \\
\text { clayey } \\
\text { silty } \\
\text { SAND) }\end{array}$ & $\begin{array}{l}\text { (silty } \\
\text { clayey } \\
\text { SAND) }\end{array}$ & \\
\hline$K_{\text {sat }}(\mathrm{m} / \mathrm{s})$ & $2.889 \mathrm{E}-6$ & $4.053 \mathrm{E}-5$ & $1.250 \mathrm{E}-6$ & $8.250 \mathrm{E}-5$ & $3.639 \mathrm{E}-6$ & $1.228 \mathrm{E}-5$ & 1 \\
\hline$\theta_{s}\left(\mathrm{~m}^{3} / \mathrm{m}^{3}\right)$ & 0.43 & 0.41 & 0.45 & 0.43 & 0.39 & 0.41 & 1 \\
\hline$\theta_{r}\left(\mathrm{~m}^{3} / \mathrm{m}^{3}\right)$ & 0.078 & 0.057 & 0.067 & 0.045 & 0.100 & 0.065 & $1 \mathrm{E}-6$ \\
\hline$n_{b c}(-)$ & 0.56 & 1.28 & 0.41 & 1.68 & 0.48 & 0.89 & - \\
\hline$\alpha_{b c}\left(\mathrm{~m}^{-1}\right)$ & 3.6 & 12.4 & 2.0 & 14.5 & 5.9 & 7.5 & - \\
\hline$n_{v g}(-)$ & - & - & - & - & - & - & 2 \\
\hline$\alpha_{v g}\left(\mathrm{~m}^{-1}\right)$ & - & - & - & - & - & - & 20 \\
\hline
\end{tabular}

